\title{
PLUMMETING CONSUMERS' BRAND SWITCHING BEHAVIOUR USING A HOLISTIC PRODUCT STRATEGY IN THE ZIMBABWEAN COLA INDUSTRY
}

\author{
Forbes Makudza \\ Business Management Department, Manicaland State University of Applied Sciences, Mutare, \\ Zimbabwe \\ forbesmakudza@gmail.com \\ Gratitude Tasara \\ Department of Finance and Marketing, Solusi University, Bulawayo, Zimbabwe \\ gratitude.tasara@gmail.com \\ Gibson Muridzi \\ Business Management Department, Manicaland State University of Applied Sciences, Mutare, \\ Zimbabwe \\ gibson.muridzi@gmail.com
}

\begin{abstract}
The study was driven by the need to elevate consumers' switching costs so as to minimise consumer churning behaviour. The purpose of this study was to examine the effect of the product strategy on consumers' brand switching intention behaviour. A marketing orientation of managing a product from a holistic approach was adopted and that was informed by previous theoretical modelling. The study followed a quantitative approach in the cola industry in Zimbabwe. Data was collected using questionnaires from a sample size of 432 respondents. Structural Equation Modeling (SEM) - Amos Graphics was used to analyse data. The study confirmed that a holistic approach to product strategy is statistically significant in minimising churning behaviour of customers. Product availability and product quality were inversely influencing behavioural intention to switch brands whilst product price recorded a significant positive impact. Product range had an insignificant association with consumer attrition. The study concluded that consumers' switching behaviour can be managed through a well implemented product strategy. To plummet brand switching behaviour, the study recommends effective product pricing, effective product distribution and improvements in product quality.
\end{abstract}

Keywords: Brand Switching, Consumer Behaviour, Marketing Mix, Product Strategy. 


\section{INTRODUCTION}

The relationship between the consumer and the company is largely on transactional exchange episodes where a consumer gets a product and the company gets economic value. The quarter inch drill - quarter inch hole of Levitt (1983) enhanced the understanding of the product from a mere core offering to value delivery and beneficiation. Conversely, the product strategy has also been largely attributed to the marketing mix as one key component (Raylton, 2021). Although Kotler, Armstrong and Oliver (2018) acknowledge that product strategy is a discrete strategy on its own, it does work in harmony with all other elements of the marketing mix to offer a holistic strategy approach.

The advent of technological developments in product development has shortened the new product development process. Coupled with stiff competition and low market entry barriers, the product life cycle is gradually becoming shorter and shorter and consumers are gradually becoming nomadic as they engage in portfolio purchasing and high switching behaviour (Ownland \& Conadis, 2020). This led to a trade-off dilemma where companies had to make a balance between product performance and efficiency as a means to elevate consumers' switching costs (Lama, 2015). Given that the product value is what the customer buys, it therefore follows that the product strategy has gradually gained a key prominence over consumer behavioural intentions in the twenty first century (Raylton, 2021).

This study therefore aims to examine the effect of the product strategy on consumers' behavioural intention. The study is based on the adaptation of the product theories of Jimenez (2005), Stantonn and Mccathyn (2009) and Gürbüz (2018), where the product strategy determinants are product pricing, product range, product availability and product quality. The study tested the model in the cola soft drink beverages industry. This study offers a unique contribution to overall marketing strategy by testing the application of the product strategy as an enhancer of consumer switching costs and an influencer of consumer behaviour. Practically, the study enhances the management of consumer products and behaviour in a volatile business environment.

\section{LITERATURE REVIEW}

\subsection{Product Strategy}

Kotler et al. (2018) define a product as anything that can be offered to the market to satisfy customers' needs and wants. Lama (2015) further adds that a product is the company's offering to its customers. Product strategy, on the other hand, is a company's deliberate strategy to offer a product to customers at the right time, right place and in the right form. It is a blueprint that aims to satisfy customers who consume those products (Yoffie, 2009). Druckler and Mackelnzie (2016) also commented that if a product strategy is poorly 
implemented, customers may perceive it negatively, leading to a loss of competitiveness. To enhance their product strategies, Makudza, Muridzi and Chirima (2019) indicate that some companies engage in business process reengineering. This intimates that a neatly crafted product strategy promotes good sales and enhances organizational competitiveness.

\subsection{Consumer Perception of a Company's Product Strategy}

Taylor, Satija, Khurana, Singh and Ebrahim (2010) define consumer perception of a product as the customer's views and beliefs about a company's product offering. Raylton (2021) concurs with Taylor et al. (2010) and further adds that consumer perception plays an integral part in consumer decision making. Products that are perceived favourably are more likely to be bought than those that are negatively perceived. Consumer perception determines the extent to which the customer's expectations of products are met (Mulla, 2011). Typically, before using a product or buying one, customers build an expectation of how the product or service should perform. They then compare that product expectation against the actual performance when they buy and use the product. In practice there is almost always a difference between the two (expectation and actual performance). The end result of the variation between actual performance of the product and the preconceived expectations leads to the development of a favourable or negative perception (Makudza, 2020).

Other company-related factors also play a major role in affecting the perception of customers in relation to the product. Andersson, Arvidsson and Lindström (2006) suggest that consumer perception is a complex phenomenon which may be influenced by the marketer using product price and how the product is promoted and distributed. Though marketers are earmarked as key influencers, Makudza, Mugarisanwa and Siziba (2020) suggested that social media and viral word-of-mouth are today building strong perceptions of the effectiveness of a company's product strategy.

\subsection{Consumer's behavioural intention to switch}

Behavioural intention shows the likely effect that certain behaviour is going to be performed (Marandu et. al., 2019). Consumers' intention to switch behaviour is the consumers' determination to move from one supplier to the other (Cronin et. al., 2000). When customers are exposed to various notable product strategies of companies, they develop an intention either to like them (intention to stay loyal) or to shun them (intention to switch). Typically, the behavioural intention to switch of customers is predicted by the strength of the consumers' perception of the product strategy of a particular company (Ebrahim et al., 2016). 
Switching behavioural intention dimension shows the extent to which customers are willing to change from their current service provider to an alternate service provider (Ownland \& Conadis, 2020).

According to the Theory of Reasoned Action (TRA) by Fishbein and Aizen (1975) and the Theory of Planned Behaviour (TPB) by Ajzen (1991) an individual's behaviour is predicted by his or her intention to perform the behaviour. Venkatesh et al. (2003) second the notion that behavioural intention predicts actual behaviour. A comprehensive review of 450 articles that measured the association between behavioural intention and actual behaviour by Ogut (2016) revealed that there is a direct linear association between the two variables. Some scholars have used behavioural intention as an independent variable (Cirpin \& Sarica, 2014; Marandu et. al., 2019). The reason behind this is the ability of behavioural intention to predict actual behaviours by customers (Marandu et al., 2019). Behavioural intention can either be positive or negative, depending on the strength of the antecedents of it. According to Al-qasa, Isa and Othman (2013) positive behavioural intention results in bonding with the service provider, a willingness to purchase from the service provider, and increased market share. On the opposite side, unfavourable behavioural intention leads consumers to show probability of brand switching, unwillingness to purchase from the service providers, and engaging in negative word-of-mouth (Makudza et al., 2020).

\subsection{Determinants of product strategy}

According to Solani (2019), identifying the main drivers of product strategy is not an easy task because there are so many factors that play a role on consumer purchasing behaviour. Jimenez (2005) however theorised that the product strategy is based on convenience, price and quality. The product strategy model of Jimenez (2005) was also supported by Nilghi (2020) who used three of Jimenez's (2005) variables as the predictors of consumer behaviour.

Stantonn and Mccathyn (2009) further theorized that the product can be classified either as consumer goods or industrial goods and can be driven by product durability, range and uniqueness. Stantonn and Mccathyn (2009) opine that a strong product strategy offers unique and durable products which are available in different forms and flavours. In another attempt to theorize the antecedents of the product strategy Gürbüz (2018) found that a viable product strategy is determined by six factors namely; physical attributes, product confidence, after-sales services, benefits, brand image and special features and guarantees. Gürbüz (2018) further indicates that a product strategy changes from time to time to cater for the ever-changing consumer behaviour.

This paper is informed by the theoretical modelling of Jimenez (2005), Stantonn and Mccathyn (2009) and Gürbüz (2018) through an adaptation approach of fusing the former's product strategy determinants and 
linking them to consumer switching behaviour. In so doing, the product strategy is understood as determined by product Price, product Range, product Availability and product Quality (PRAQ).

\subsubsection{Product price}

According to Jimenez (2005), price is a value or reward provided in exchange for need satisfaction. The product's price and the consumers' perception of value should be compatible. Price relates directly to the generation of revenue and ultimately organizational profits (Paracha et al., 2012). It is the only variable that a marketer can change quickly to respond to changes in demand or to actions of competitors (Lal \& Pankaj, 2017). Jimenez (2005) indicates that product pricing is determined by the value attached to the product, price sensitivity of the market, type of product (whether convenient, shopping, specialty or unsought product), competition, and governmental regulations.

Paracha et al. (2012) found that product price was a key determinant in establishing preference of a brand. Respondents agreed to the notion that they considered price of products before deciding to buy from either of the two. A related study by Hou et al. (2021) found that price was an invariably congruent determinant of consumer behaviour in online platforms. Hou et al. (2021) also found a related relationship between the price of the product itself and consumers' perception of quality. Putra et al. (2021) found that perceived price had a higher effect on perceived value and customer loyalty, whilst Drawnilise (2020)'s study found that product price was the second most important predictor of consumer loyalty behaviour, the first being product quality. In light of the foregoing discussion, we opine that price of a product directly impacts switching costs amid customers' churning behaviour. We therefore posit the following:

$H_{1}$ : There is a positive association between product pricing and consumer's behavioural intention to switch brands.

\subsubsection{Product range}

Jimenez (2005) posits that product range refers to variations of a product that a company produces. The same product may be produced in different flavours and package sizes (Stantonn \& Mccathyn, 2009). The essence of product range on consumer behaviour is developed in this study's model in three forms. The first aspect is the product variety which allows the firm to better meet the demands of heterogeneous consumers. Secondly, a broad product range can erect entry barriers by strategically pre-empting new market entrants and, thirdly, multiple products allow the firm to reduce competition through mutual forbearance (Stantonn \& Mccathyn, 2009; Jimenez, 2005). 
An empirical study by Tjahjaningsih Ningsih and Utomo (2020) found that product range and diversity influence customer satisfaction and enhance word-of-mouth marketing. Although Drawnilise (2020) also examined the effect of product range, its impact was found to be low, though statistically significantly affecting consumer behaviour. Mulla (2011) also concluded that range of products acted as a significant determinant of consumer behaviour in the cola beverages industry.

Therefore, the following hypothesis was developed for this study:

$\mathrm{H}_{2}$ : There is an inverse association between product range and consumer's behavioural intention to switch brands.

\subsubsection{Product availability}

Product availability refers to the extent to which a product or company offering is easily accessible in the right form, place, time and assortment (Kotler et al., 2018). It also affects consistency in product delivery. Stantonn and Mccathyn (2009) posit that a strong product strategy offers unique and durable products which are made available to customers in different forms and flavours. When a product is sometimes not available on the shelf of major stores, customers may perceive the brand as being inconsistent (Gronroos, 1990; Kotler et al., 2018).

A sample from a systematic study by Paracha et al. (2012) agreed that if one brand is not readily available, customers would buy the existing brand. Their study further notes that absence of a product on the shelf may drive loyal customers to test other brands, thereby reducing switching costs. Tantiwongwat (2013) explained that Coca-Cola gained more market share over Pepsi-Cola in other regions because Coca-Cola increased product availability capitalizing on Pepsi's absence; hence, consumers who preferred Pepsi tended to substitute it with Coca-Cola. Conversely, Maumbe et al. (2019) expressed product availability as the driver of market share in the cola beverages industry as poorly distributed products lost market share to intensive distributors.

The study thus makes the following proposition:

$H_{3}$ : There is an inverse association between product availability and consumers' behavioural intention to switch brands.

\subsubsection{Product quality}

Product quality is the collection of characteristics or attributes of a product or service that relies on its ability to fulfil stated or implied needs (Chris, 2014). The relationship between quality and behavioural intention is complex. Product quality may have a direct or indirect effect on behavioural intention (Jimenez, 2005). The 
Makudza, F., Tasara, G. \& Muridzi, G.

PLUMMETING CONSUMERS' BRAND SWITCHING BEHAVIOUR THROUGH A HOLISTIC PRODUCT STRATEGY IN THE COLA INDUSTRY

higher the product quality, the stronger the intention for customers to stay loyal and the opposite also holds true for poor product quality. According to Makudza (2020), product quality perception is developed from the variance between customers' quality expectation and perceived quality. Expected quality is built through marketing communication, individual needs, and viral communications. Perceived quality is influenced by an experience of both technical and functional quality aspects of the product (Gürbüz, 2018; Makudza, 2020). Previous studies also confirm the role of quality on consumer switching behaviour. Paracha et al. (2012) found out that $44.50 \%$ of the sample strongly agreed that the taste and quality of the product influenced their brand selection. Hou et al. (2021) concluded that product quality is a key determinant in the decision of customers to buy from a collection of online brands.

The study therefore hypothesises that:

$\mathrm{H}_{4}$ : There is an inverse association between product quality and consumers' behavioural intention to switch brands.

Figure 1 presents the conceptual framework for the study.

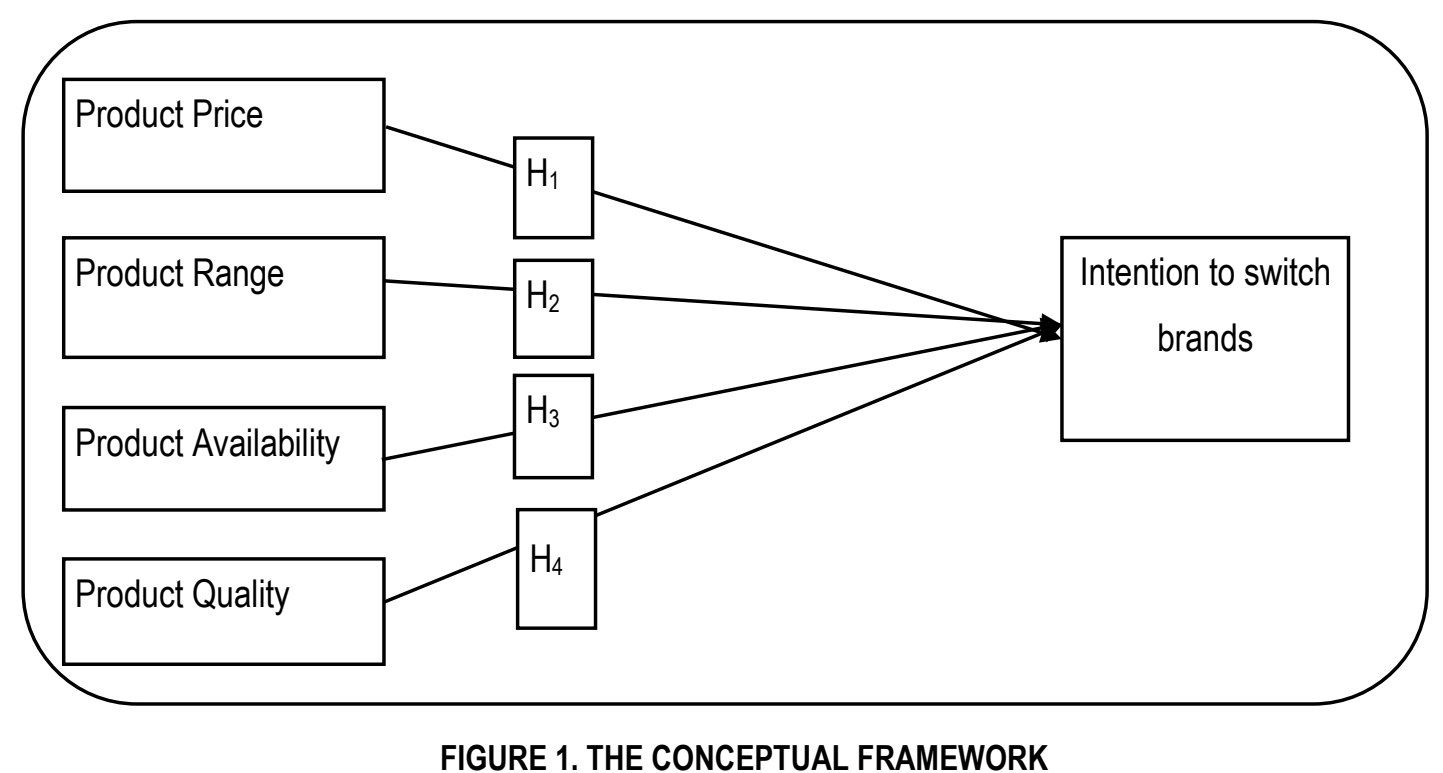

Source: By the authors

Thus, the following equation was tested:

Intention to Switch $\left.=\beta_{0}+\beta_{1} P P+\beta_{2} P R+\beta_{3} P A+\beta_{4} P Q+\varepsilon\right)$

Where $\mathrm{PP}$ is product price, $\mathrm{PR}$ is product range, $\mathrm{PA}$ is product availability and $\mathrm{PQ}$ is product quality. 
Makudza, F., Tasara, G. \& Muridzi, G.

\section{PLUMMETING CONSUMERS' BRAND SWITCHING BEHAVIOUR THROUGH A HOLISTIC PRODUCT STRATEGY IN THE COLA INDUSTRY}

\section{METHODOLOGY}

The study followed the positivism philosophy in trying to quantify the differential effect of the product strategy on consumers' brand switching behaviour. Quantitative methods were therefore used to unpack consumer behaviour and product strategy. The target population of the study was made up of cola beverage customers. Coca-Cola and Pepsi-Cola were the two major brands which were targeted as most consumers had undergone the taste-testing phases of both brands, thus enhancing collection of data from the right group.

The study further applied cluster sampling by focusing on customers who were loyal to Coca-Cola. All customers who indicated that they were loyal to Pepsi-Cola were eliminated from the study. This was deliberately done in order to establish the switching intention of Coca-Cola's loyal customers without the influence of customers who had already switched to Pepsi-Cola. Although the study attracted 432 respondents, only 257 respondents who professed brand patronage of Coca-Cola were used to test the study model. The minimum sample size was determined using the Krejcie and Morgan (1970) sample size framework However, guided by Saunders et. al., (2015) the study further adjusted upwards the minimum sample size to cater for non-responses. The sample size was deemed representative of the entire population as it was generated at $95 \%$ confidence level and $5 \%$ margin of error. Data was collected using questionnaires and the study was conducted in an ethically and morally upright manner while respondents' right to withdraw, voluntary participation, and informed consent were upheld. SPSS-AMOS was used to analyse the data.

\section{RESULTS AND DISCUSSION}

\subsection{Sample distribution}

Table 1 shows the frequency distribution.

TABLE 1. SAMPLE DISTRIBUTION

\begin{tabular}{|l|l|c|c|}
\hline Aspect & Distribution & Frequency & Per cent (\%) \\
\hline \multirow{4}{*}{ Gender } & Male & 200 & 46.3 \\
\cline { 2 - 4 } & Female & 232 & 53.7 \\
\cline { 2 - 4 } & Total & 432 & 100.0 \\
\hline \multirow{4}{*}{ Age } & Below 20 & 30 & 6.9 \\
\cline { 2 - 4 } & 21 to 30 & 147 & 34.0 \\
\cline { 2 - 4 } & 31 to 40 & 175 & 40.5 \\
\cline { 3 - 4 } & 41 to 50 & 68 & 15.7 \\
\cline { 2 - 4 } & Above 50 & 12 & 2.8 \\
\cline { 2 - 4 } & Total & 432 & 100.0 \\
\hline \multirow{2}{*}{$\begin{array}{l}\text { Knowledge of cola } \\
\text { products }\end{array}$} & Yes & 432 & 100 \\
\cline { 2 - 4 } & No & 0 & 0 \\
\hline
\end{tabular}


Makudza, F., Tasara, G. \& Muridzi, G.

PLUMMETING CONSUMERS' BRAND SWITCHING BEHAVIOUR THROUGH A HOLISTIC PRODUCT STRATEGY IN THE COLA INDUSTRY

\begin{tabular}{|l|l|c|c|}
\hline & Total & $\mathbf{4 3 2}$ & 100.0 \\
\hline \multirow{3}{*}{ Brand Preference } & Coke & 257 & 59.5 \\
\cline { 2 - 4 } & Pepsi-Cola & 175 & 40.5 \\
\cline { 2 - 4 } & Total & $\mathbf{4 3 2}$ & $\mathbf{1 0 0 . 0}$ \\
\hline \multirow{3}{*}{$\begin{array}{c}\text { Consumption } \\
\text { Frequency }\end{array}$} & Monthly & 132 & 30.6 \\
\cline { 2 - 4 } & Fortnightly & 153 & 35.4 \\
\cline { 2 - 4 } & Weekly & 90 & 20.8 \\
\cline { 2 - 4 } & Daily & 57 & 13.2 \\
\cline { 2 - 4 } & Total & $\mathbf{4 3 2}$ & $\mathbf{1 0 0 . 0}$ \\
\hline
\end{tabular}

Source: Research findings computed using SPSS

Table 1. shows that females outnumbered male respondents, whilst young adults aged between 30 and 40 years of age dominated the study (40.5\%). The least represented age group is of those above 50 years, constituting $(2.8 \%)$. Given that data was randomly collected, these results suggest that females are more active consumers of soft drinks than males, and that young adults enjoy soft drink beverages more in comparison to the elderly and the young.

Through data cleaning, the study eliminated all responses who were not aware of the two brands under study. This left behind 432 validated responses who were conscious of both Coca-Cola and Pepsi-Cola products. The study further eliminated 175 responses of customers who were loyal to Pepsi-cola and focused specifically on 257 respondents whose loyalty rested with Coca-Cola. This was done to measure the brand switching intention of loyal customers of Coke to Pepsi-Cola. Regardless of the foregoing, the study managed to validate that Coca-Cola is still the preferred brand in the Cola market with a 59.5\% loyalty index against Pepsi-Cola's $40.5 \%$. Soft drink beverages are purchased more infrequently as the majority of respondents confirmed that they buy soft drinks fortnightly (35.4\%) and monthly (30.6\%).

\subsection{Exploratory Factor Analysis (EFA)}

The study followed the recommendations of Kline (2005) that there is need to reconnoiter questionnaire items to verify whether they affirm their dimensions through EFA. EFA is a principal tool for multivariate dimension reduction and it should be followed by another confirming test statistic (Kline, 2005; Schmitt, 2011). Guided by the aforementioned literature, the study conducted the EFA for the suggested model. Kaiser-Meyer-Olkin's Measure of Sampling Adequacy score was 0.857 whilst Bartlett's Test of Sphericity was statistically significant $\left(X^{2}=3199.18 ; D F=120 ; P=0.00 ; P<0.05\right)$. This proved that the data was suitable for analysis. A Varimax rotation factor analysis confirmed each measurement item loaded to the corresponding component, and four independent components emerged namely product price, product 
Makudza, F., Tasara, G. \& Muridzi, G.

PLUMMETING CONSUMERS' BRAND SWITCHING BEHAVIOUR THROUGH A HOLISTIC PRODUCT

STRATEGY IN THE COLA INDUSTRY

range, product availability and product quality. The least loading had 0.713 whilst the highest recorded was 0.876 . All these loadings were above the cut-off threshold of 0.50 (Pallant, 2005).

\subsection{Confirmatory Factor Analysis (CFA)}

A confirmatory factor analysis was conducted in $A M O S \cap$ to examine the divergent and convergent validity, as well as to examine the measurement model. The study also analysed the reliability of the instrument. The CFA results indicated a good model fit $(C M I N=172.2, D F=92, P=0.00, C M I N / D F=$ 1.873, GFI $=0.953, \mathrm{AGFI}=0.931 ; \mathrm{CFI}=0.974, \mathrm{RMSEA}=0.045)$. The conclusion on the model fit threshold was based on Hair et al. (2010). The model was therefore worth using in this study. Table 2 shows the results of the CFA.

TABLE 2. CONFIRMATORY FACTOR ANALYSIS

\begin{tabular}{|c|c|c|c|c|c|}
\hline Factors & Item & Standard Loadings & Cronbach Alpha & Composite reliability & AVE \\
\hline \multirow[t]{4}{*}{ Product Price } & PP1 & 0.77 & \multirow[t]{4}{*}{0.73} & \multirow[t]{4}{*}{0.88} & \multirow[t]{4}{*}{0.65} \\
\hline & PP2 & 0.65 & & & \\
\hline & PP3 & 0.89 & & & \\
\hline & PP4 & 0.90 & & & \\
\hline \multirow[t]{4}{*}{ Product Range } & PR1 & 0.84 & \multirow[t]{4}{*}{0.829} & \multirow[t]{4}{*}{0.90} & \multirow[t]{4}{*}{0.69} \\
\hline & PR2 & 0.85 & & & \\
\hline & PR3 & 0.88 & & & \\
\hline & PR4 & 0.75 & & & \\
\hline \multirow[t]{4}{*}{ Product Availability } & PA1 & 0.67 & \multirow[t]{4}{*}{0.897} & \multirow[t]{4}{*}{0.82} & \multirow[t]{4}{*}{0.53} \\
\hline & PA2 & 0.77 & & & \\
\hline & PA3 & 0.77 & & & \\
\hline & PA4 & 0.71 & & & \\
\hline \multirow[t]{4}{*}{ Product Quality } & PQ1 & 0.76 & \multirow[t]{4}{*}{0.76} & \multirow[t]{4}{*}{0.81} & \multirow[t]{4}{*}{0.52} \\
\hline & PQ2 & 0.68 & & & \\
\hline & PQ3 & 0.67 & & & \\
\hline & PQ4 & 0.77 & & & \\
\hline \multirow[t]{4}{*}{ Behavioural Intention } & $\mathrm{BI} 1$ & 0.71 & \multirow[t]{4}{*}{0.81} & \multirow[t]{4}{*}{0.81} & \multirow[t]{4}{*}{0.52} \\
\hline & $\mathrm{B} 12$ & 0.77 & & & \\
\hline & $\mathrm{B} 13$ & 0.62 & & & \\
\hline & $\mathrm{B} 14$ & 0.76 & & & \\
\hline
\end{tabular}

Source: Research findings processed by SPPS-AMOS

From Table 2, the study assessed the convergent validity and reliability through consideration of factor loadings, Cronbach Alpha, Composite Reliability, and Average Variance Extracted (AVE). The results demonstrate high factor loadings which range from 0.65 to 0.90 . According to Hair et al., (2010), the minimum cut-off point is 0.5 . This therefore supports the notion that indicators were closely related and were measuring underlying latent factors. The Composite Reliability and the Cronbach Alpha statistics 
ranked 0.73 and above. Hair et al. (2010) suggested a minimum threshold of 0.70 , hence validating the reliability of the indicators. Furthermore, the AVE for all latent factors were 0.52 and above. This surpassed the minimum threshold of 0.5 (Hair et al., 2010).

Table 3 shows the results of the discriminant validity.

TABLE 3. DISCRIMINANT VALIDITY

\begin{tabular}{|l|r|r|r|l|l|}
\hline & $\begin{array}{l}\text { Product } \\
\text { Price }\end{array}$ & $\begin{array}{l}\text { Product } \\
\text { Range }\end{array}$ & $\begin{array}{l}\text { Product } \\
\text { Availability }\end{array}$ & $\begin{array}{l}\text { Product } \\
\text { Quality }\end{array}$ & $\begin{array}{l}\text { Behavioural Intention to } \\
\text { switch brands }\end{array}$ \\
\hline Product Price & $\mathbf{0 . 8 0 8 9 3}$ & & & & \\
\hline Product Range & 0.405 & $\mathbf{0 . 6 3 6 3 9}$ & & & \\
\hline Product Availability & -0.441 & -0.213 & $\mathbf{0 . 8 3 1 8 2}$ & & \\
\hline Product Quality & -0.731 & -0.628 & 0.587 & $\mathbf{0 . 7 6 6 1 5}$ & \\
\hline $\begin{array}{l}\text { Behavioural Intention to } \\
\text { switch brands }\end{array}$ & 0.698 & 0.097 & -0.507 & -0.601 & $\mathbf{0 . 7 1 8 0 5}$ \\
\hline
\end{tabular}

Source: Research findings processed from SPPS-AMOS

Table 3 shows that the square root of the average variance extracted was higher than the correlation between the latent factors. These results therefore provide evidence of discriminant validity through the recommendations of Hair et al., (2010) and Byrne (2004). The same table also presents correlations between study constructs. Of interest is the statistically significant inverse associations between behavioural intention and product quality $(-0.60)$ and product availability $(-0.51)$. A strong positive correlation was established between behavioural intention to switch brands and product price whilst an insignificant association was recorded between behavioural intention and product range.

\subsection{Path analysis}

To test the impact of the association between product strategy and behavioural intention to switch, a structural model of intention was analysed. Figure 2 presents the structural model, with path results and $R^{2}$. 
Makudza, F., Tasara, G. \& Muridzi, G.

PLUMMETING CONSUMERS' BRAND SWITCHING BEHAVIOUR THROUGH A HOLISTIC PRODUCT

STRATEGY IN THE COLA INDUSTRY

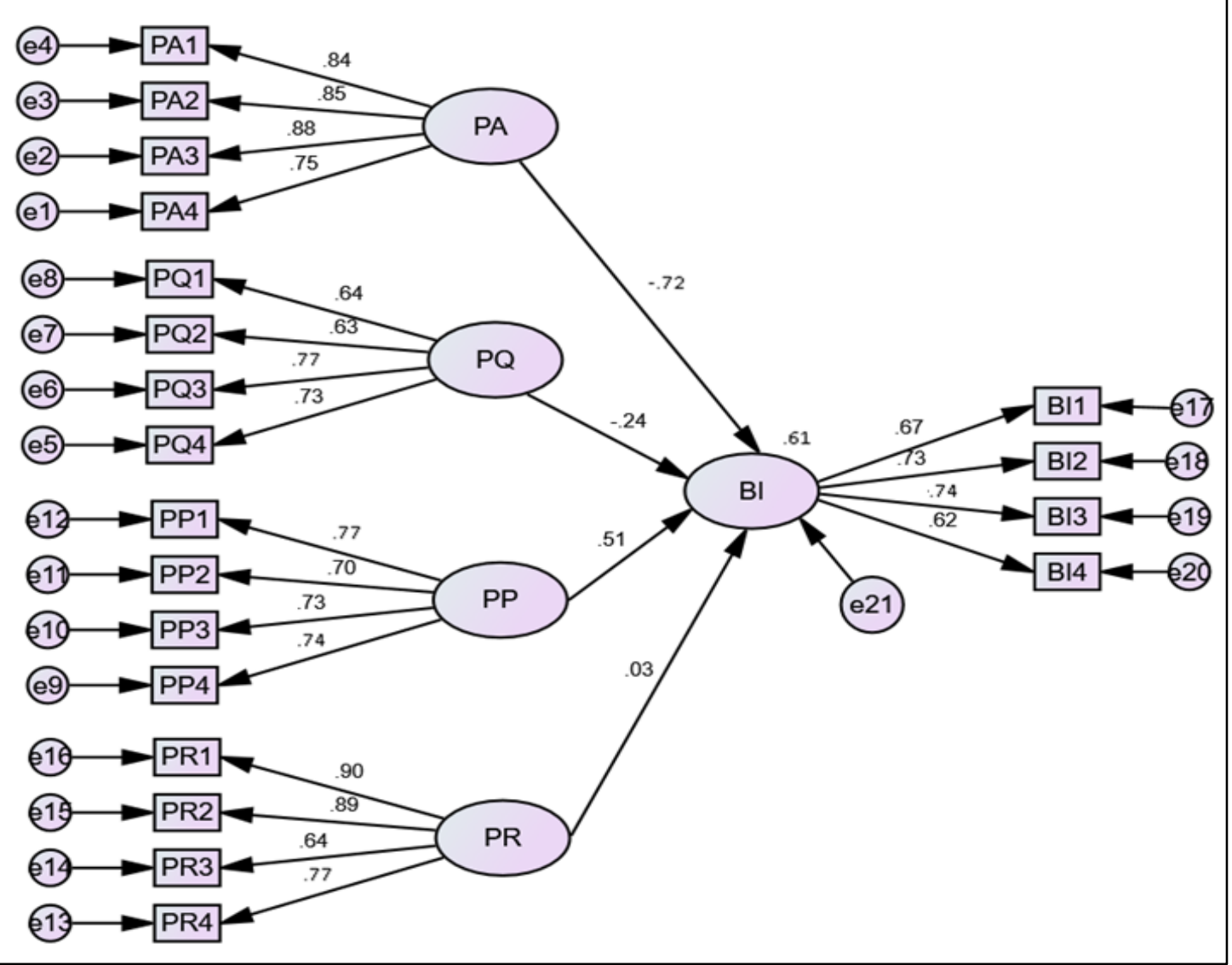

FIGURE 2. PATH COEFFIECIENCY

Source: The Authors

Where $\mathrm{PA}$ is product availability; $\mathrm{PQ}$ is product quality, $\mathrm{PP}$ is product price and $\mathrm{PR}$ is product range.

The structural model in Figure 2 was a good fit (CMIN 290.02, $d f=106, P=0.00, C M I N / D F=2.193$, GFI $=951, \mathrm{AGF}=0.927 ; \mathrm{CFI}=0.962, \mathrm{RMSEA}=0.054)$. The $\mathrm{R}^{2}$ of the model was 0.61 indicating that the model managed to capture and explain $61 \%$ of the factors that drive brand switching behaviour. Figure 2 also shows that product strategy in the soft drink beverages industry has inverse impacts with behavioural intention to switch brands on latent variables; product availability and product quality, whilst positive impacts were experienced on product price and product range. Table 4 shows the levels of significance for the structural model. 
Makudza, F., Tasara, G. \& Muridzi, G.

PLUMMETING CONSUMERS' BRAND SWITCHING BEHAVIOUR THROUGH A HOLISTIC PRODUCT STRATEGY IN

THE COLA INDUSTRY

TABLE 4. SIGNIFICANCE OF THE STUDY'S ASSOCIATIONS

\begin{tabular}{|l|l|l|c|l|l|l|l|}
\hline & & & Standardized Coefficients & S.E. & C.R. & P & Decision \\
\hline BI & $<--$ & PA & -0.723 & 0.031 & -5.397 & 0.000 & Supported \\
\hline BI & $<--$ & PQ & -0.241 & 0.071 & -4.031 & 0.000 & Supported \\
\hline BI & $<--$ & PP & 0.512 & 0.097 & 6.850 & 0.000 & Supported \\
\hline BI & $<--$ & PR & 0.028 & 0.055 & .498 & 0.619 & Rejected \\
\hline
\end{tabular}

Source: Research findings processed from AMOS

\section{DISCUSSION OF FINDINGS}

The first hypothesis tested the association between intention to switch brands and product pricing strategy $(\beta=0.512, P=0.00, r=0.698)$. The results thus show that product pricing has a strong, significant, and positive impact on churning behaviour and $\mathrm{H} 1$ was supported. The conclusion on the first hypothesis means that consumers are price sensitive. Therefore, if cola product prices are hiked, customers will switch to competing brands. This therefore suggests the need for a low-cost leadership strategy against consumer attrition woes.

Empirical studies also had similar findings; Hou et al. (2021) found out that product price was an invariably congruent determinant of consumer online interactions. Similarly, Garbario and Slonim (2003) found a positive association between price and perceived expensiveness. Other studies also came to the same conclusion (Drawnilise, 2020; Lichtenstein \& Ridgway, 2013; Paracha et al., 2012; Putra, Jayadi \& Steven, 2021).

The second hypothesis between product range and behavioural intention to switch brands was not statistically significant $(\beta=0.028, P=0.619)$. The study therefore rejects the alternate hypothesis and concludes that there is evidence of a statistically insignificant association between product range and behavioural intention to switch brands. This shows that consumers' decision to buy is not driven by the range of products that brands offer.

The study produced slightly different results from examined empirical studies. Drawnilise (2020) found out that product range was statistically significant with a positive but weak association with brand loyalty. Tantiwongwat (2013) also found a weak but significant association between the two variables. However, results from the study showed that there is no association between product range and consumers' intention to switch from one brand to the other.

The third hypothesis measured the association between product availability and consumers' behavioural intention to switch brands. Study results show a significant inverse association between the two variables $(\beta=-0.723, P=0.00, r=-0.507)$. Consumers may switch from one brand to the other if their 
loyal brand is not readily available on the shelves. The high impact factor of $73 \%$ demonstrates the strong conviction of consumers to switch from brands which are not available in the market. The association was also negative meaning that, if a loyal brand is not readily available, customers will easily switch to a competing brand if it is available.

Previous studies have also confirmed the need to make products easily available. Paracha et al. (2012) found that if one brand is not readily available customers switch to available brands. Mulla (2011) also found an inverse association between product availability and consumer switching behaviour.

The fourth hypothesis examined the relationship between product quality and behavioural intention to switch brands. Statistical results in Table 4 show that the association between product quality and consumers' behavioral intention to switch brands was statistically significant $(\beta=-0.24, P=0.00)$. The strength and direction of the association was shown by the correlation coefficient of -0.601 ; which shows a strong but negative association between product quality and consumer intention. We therefore accept the alternate hypothesis and conclude that there is statistical evidence of an inverse association between product quality and consumers' behavioral intention to switch brands.

The interpretation of the results is that product quality really affects consumers' brand switching behaviour. The higher the product quality, the lower the consumers' intention to switch to competing brands. Therefore, enhancement of product quality reduces churning behaviour. Previous research findings were closely aligned to the findings of this study. Paracha et al. (2012) found that $44.5 \%$ of the sample strongly agreed that the taste and quality of the product influenced their brand selection. Hou et al. (2021) concluded that product quality is a key determinant in the decision of customers to buy from a collection of online brands. Ownland and Conadis (2020) also found that cola customers were better moved to buying from a particular brand based on quality. Meanwhile, Ladhari and Morales (2011) concurred with the current results.

\section{CONCLUSIONS AND IMPLICATIONS}

The study validated the strategic marketing significance of the product strategy on consumer behaviour and therefore concludes that a strong product strategy elevates consumer's switching costs and minimises consumers' churning behaviour. The study further concludes that product quality and product availability have an inverse association with brand switching behaviour whilst product pricing has a positive impact. Further to that, the study also concluded that product range does not influence brand switching behaviour of consumers. 
These conclusions have marketing and practical managerial implications for the cola beverages industry and other related sectors. The study's findings indicate the touch points that drive consumer loyalty through the minimisation of consumer attrition. These factors include enhancement of the product availability strategy through extensive distribution of products and the enhancement of quality through continuous improvement. The study also informs the pricing strategy of companies and makes a strong case for a cost leadership strategy where the market is price sensitive.

The study suffered some few limitations. It was limited to only two brands (Coca-Cola and Pepsi-Cola) regardless of the existence of other small brands in the cola industry. However, this was done to ensure comparability as other cola brands do not have a global and countrywide coverage/ presence. Hence to isolate switching behaviour based on market coverage, two brands with global and national coverage were considered. Another limitation was that the product strategy was understood by just analyzing four variables, namely price, quality, range and availability. There may be other factors that also affect product strategy as proven by an $R^{2}$ of 0.61 , which means that there are other factors which account for $39 \%$ of the behavioural impact on consumers. Regardless of the aforementioned limitations, the study managed to offer a validated model which future researchers may want to test in various target groups.

\section{REFERENCES}

Ajzen, I. (1991). The theory of planned behaviour, organisational behaviour and human decision processes. Journal of Theoretical and Applied Information Technology. 50(1), 179-211.

Al-qasa, K., Isa, F. \& Othman, S. (2013). Factors affecting intentions to use banking services in Yemen. Journal of Internet Banking and Commerce, 18(2), 45-56.

Andersson, E., Arvidsson, E. \& Linstrom, C. (2006). Coca-Cola or Pepsi; that is the Question - A study about different factors affecting consumer preferences. International Marketing Journal, 22(1), 12211243.

Byrne, B. M. (2004). Testing for multigroup invariance using AMOS graphics: A road less travelled. Structural Equation Modelling, 11(2), 272-300. https://doi.org/10. 1207/s15328007sem1102 8

Chris, D. (2014). Product attributes and brand equity in the mobile domain: The mediating role of customer experience. International Journal of Information Management, 32(2), 139-146. https://doi.org/10.1016/ji.jinfomgt.2011.11.017

Cirpin, B., \& Sarica, K. (2014). Measuring service quality in banking industry: A case study from Turkey. Istanbul University Journal of the School of Business, 43(2), 205-217. 


\section{PLUMMETING CONSUMERS' BRAND SWITCHING BEHAVIOUR THROUGH A HOLISTIC PRODUCT STRATEGY IN THE COLA INDUSTRY}

Cronin, J., Brady, M. \& Hult, T. (2000). Assessing the effects of quality, value, and customer satisfaction on consumer behavioral intentions in service environments. Journal of Retailing, 76(2), 193-218.

Drawnilise, D. (2020). The impact of the product strategy on brand loyalty. International Journal of Marketing and Brand Management, 3(1), 15-24.

Druckler, P. \& Mackelnzie, V., (2016). Cola Preferences: disguised taste vs. brand evaluation. Advances in Consumer Research, 5(1), 18.

Ebrahim, R., Ghoneim, G., Irani, Z. \& Fan, Y. (2016). A brand preference and repurchase intention model: the role of consumer experience, Journal of Marketing Management, 32(1), 1230-1259, https://doi.org/10.1080/0267257X.2016.1150322.

Fishbein, M. \& Ajzen, I. (1975). Belief, Attitude, Intention, and Behavior: An Introduction to Theory and Research. Addison-Wesley, Reading, MA.

Garbario E. \& Slonim, R. (2003). Interrelationships and distinct effects of internal reference prices on perceived expensiveness. Psychology and Marketing, 20(3), 227-48.

Gronroos, C. (1990). Marketing services: the case of a missing product. The Journal of Business \& Industrial Marketing, 13(4/5), 322-338.

Gürbüz, E. (2018). Theory of new product development and its applications. IntechOpen. http://dx.doi.org/10.5772/intechopen.74527.

Hair, J. F. Black, W. C. Babin, B. J. \& Anderson, R. E. (2010). Multivariate data analysis. Prentice Hall, Upper Saddle River, NJ.

Hou, R., Zhao, Y., Zhu, M. \& Xiaogang, L. (2021). Price and quality decision in a vertically-differentiated supply chain with an online to store channel. Journal of Retailing and Consumer Services, 62(1), 1 12.

Jimenez, C. (2005). Price, quality and convenience as predictors of consumer purchasing of sustainable products. Texas State University, Texas, USA.

Kline, R. B. (2005). Principles and practice of structural equation modelling, $2^{\text {nd }} E d$, Guilford Press.

Kotler, P., Armstrong, G. \& Oliver, M. (2018). Principles of marketing, 17th Edition. Global Ed. Harlow: Pearson.

Krejcie, R. V. \& Morgan, D. W. (1970). Determining sample size for research activities. Educational and Psychological Measurement, 30(1) 607-610.

Ladhari, Y. \& Morales, U. (2011). Implementing total quality management: the role of human resource management, SAM Advanced Management Journal, 59(2), 10-17. 
Makudza, F., Tasara, G. \& Muridzi, G.

PLUMMETING CONSUMERS' BRAND SWITCHING BEHAVIOUR THROUGH A HOLISTIC PRODUCT STRATEGY IN

THE COLA INDUSTRY

Lal, B. \& Pankaj, P. (2017). Customer satisfaction towards Pepsi and Coca-Cola: an exploratory study of Jind City (Haryana). International Journal of Research in Management, Economics and Commerce, 7(8), 33-39.

Lama, A. (2015). Niching versus change-of-pace using purchase frequencies \& penetration rates to infer brand positioning. Journal of Marketing Research, 25(4), 384-390.

Levitt, T. (1983). The marketing imagination. New York: Free Press.

Lichtenstein, N. M. \& Ridgway, R. G. (2013). Price perceptions and consumer shopping behavior: a field study. Journal of Marketing Research, 30(1), 234-235.

Makudza, F. (2020). Augmenting customer loyalty through customer experience management in the banking industry. Journal of Asian Business and Economic Studies, https://doi.org/10.1108/JABES01-2020-0007.

Makudza, F., Mugarisanwa, C. \& Siziba, S. (2020). The effect of social media on consumer purchase behaviour in the mobile telephony industry in Zimbabwe. Dutch Journal of Finance and Management, 4(2), 1-10, em0065. https://doi.org/10.29333/difm/9299.

Makudza, F., Muridzi, G. \& Chirima, D. T. (2019). An analysis of the business process reengineering (BPR) implementation practices and their impact on customer satisfaction in the banking sector. Amity Journal of Marketing, 4(1), 24-40.

Marandu, E. E., Makudza, F. \& Ngwenya, S. (2019). Predicting students' intention and actual use of elearning using the technology acceptance model: a case from Zimbabwe. International Journal of Learning, Teaching and Educational Research, 18(6), 110-127, https://doi.org/10.26803/ijlter.18.6.7.

Maumbe, B. M., Musekiwa, A. \& Makudza, F. (2020). Coca-Cola franchising business model: the case of Mutare Bottling Company in Zimbabwe. International Journal of Business Marketing and Management, 5(7), 1-8.

Mulla, J. V. (2011). Comparative Study of service provided by PepsiCo \& Coca-Cola at neural enterprises in Solapur. S.N.G. Institute of Management and Research Rajgurunagar, Pune.

Nilghi, N. (2020). Convenience, price and product quality as predictors of consumer behaviour. International Journal of Product and Ethical Studies, 1(2), 23-34.

Ownland, O. \& Conadis, C. (2020). An examination of the strategic impact of product quality. A case of Coca Cola in Italy. Contemporary Journal of Business and Economic Research, 3(1), 14-27.

Pallant, J. (2005). SPSS survival manual: a step-by-step guide to data analysis using SPSS for Windows. Crows Nest, Australia: Allen \& Unwin.

Paracha, A., Waqas, M., Khan, A. R. \& Ahmad, S. (2012). Consumer preference Coca Cola versus PepsiCola. Global Journal of Management and Business Research, 12(12), 12-24. 


\section{PLUMMETING CONSUMERS' BRAND SWITCHING BEHAVIOUR THROUGH A HOLISTIC PRODUCT STRATEGY IN THE COLA INDUSTRY}

Putra, P., Jayadi, R. \& Steven, I. (2021). The impact of quality and price on the loyalty of electronic money users: Empirical evidence from Indonesia. The Journal of Asian Finance, Economics and Business, 8(3), 1349-1359.

Raylton, R. (2021). The impact of consumer perception on consumer decision making. Global Journal of Social and Economic Studies, 4(1), 12-25.

Saunders, M. N. Lewis, P. \& Thornhill, A. (2015). Research methods for business students. $7^{\text {th }}$ Edition. Pearson, New York.

Schmitt, T. A. (2011). Current methodological considerations in exploratory and confirmatory factor analysis. Journal of Psychoeducational Assessment, 29(4), 304-321 https://doi.org/10.1177/0734282911406653.

Solani, S. (2019). Theorising the determinants of product strategy. International Journal of Social and Environmental Studies, 3(4), 22-29.

Stantonn, M. \& Mccathyn, S. (2009). Modelling the product strategy for competitive business environments. International Journal of Marketing and Behavioural Studies, 2(1), 1-16.

Tantiwongwat, U. (2013). Local brand versus global brand: A case study of the cola soft drink industry in Thailand. Karlstad University. Karlstad, Thailand.

Taylor, F., Satija, A., Khurana, S., Singh, G., \& Ebrahim, H. (2010). Pepsi and Coca Cola in Delhi, India: availability, price and sales. Public Health Nutrition: 14(4), 653-660.

Tjahjaningsih, E., Ningsih, D. H. \& Utomo, A. G. (2020). The effect of service quality and product diversity on customer loyalty: the role of customer satisfaction and word of mouth. The Journal of Asian Finance, Economics and Business, 7(12), 481 - 490.

Venkatesh, V., Morris, M. G., Davis, G. B. \& Davis, F. D. (2003). User acceptance of information technology: toward a unified view. MIS Quarterly. 27(3), 425 - 478.

Yoffie, D. B. (2009). Cola wars continue: Coke and Pepsi in 2006. Harvard Business School. 9(1), 706447. 